University of Nebraska - Lincoln

DigitalCommons@University of Nebraska - Lincoln

8-28-2012

\title{
Flow, nutrients, and light availability influence Neotropical epilithon biomass and stoichiometry
}

Tyler J. Kohler

Thomas N. Heatherly II

Rana W. El-Sabaawi

Eugenia Zandona

Michael C. Marshall

See next page for additional authors

Follow this and additional works at: https://digitalcommons.unl.edu/natrespapers

Part of the Natural Resources and Conservation Commons, Natural Resources Management and Policy Commons, and the Other Environmental Sciences Commons

This Article is brought to you for free and open access by the Natural Resources, School of at DigitalCommons@University of Nebraska - Lincoln. It has been accepted for inclusion in Papers in Natural Resources by an authorized administrator of DigitalCommons@University of Nebraska - Lincoln. 


\section{Authors}

Tyler J. Kohler, Thomas N. Heatherly II, Rana W. El-Sabaawi, Eugenia Zandona, Michael C. Marshall, Alexander S. Flecker, Catherine M. Pringle, David N. Reznick, and Steven A. Thomas 


\title{
Flow, nutrients, and light availability influence Neotropical epilithon biomass and stoichiometry
}

\author{
Tyler J. Kohler ${ }^{1,6}$, Thomas N. Heatherly, II ${ }^{1,7}$, Rana W. El-Sabaawi, ${ }^{2,8}$ \\ Eugenia Zandonà ${ }^{3,9}$, Michael C. Marshall ${ }^{4,10}$, Alexander S. Flecker ${ }^{2,11}$, \\ Catherine M. Pringle ${ }^{4,12}$, David N. Reznick ${ }^{5,13}$, AND Steven A. Thomas ${ }^{1,14}$ \\ ${ }^{1}$ University of Nebraska Lincoln, School of Natural Resources, Lincoln, Nebraska 68583 USA \\ ${ }^{2}$ Cornell University, Department of Ecology and Evolutionary Biology, Ithaca, New York 14853 USA \\ ${ }^{3}$ Drexel University, Department of Biology, Philadelphia, Pennsylvania 19104 USA \\ ${ }^{4}$ University of Georgia, Odum School of Ecology, Athens, Georgia 30602 USA \\ ${ }^{5}$ University of California, Department of Biology, Riverside, California 92521 USA
}

\begin{abstract}
Light, nutrient availability, and flow are strong factors controlling the elemental composition and biomass of epilithon in temperate stream ecosystems. However, comparatively little is known about these relationships in tropical streams. We investigated how gradients of light and nutrient availability, seasonality, and habitat influenced epilithon biomass, chlorophyll $a$, and nutrient ratios in montane streams of Trinidad, West Indies. We sampled 4 focal tributaries of a single river, 2 of which had canopies experimentally thinned, every other month over a 2-y period to observe temporal dynamics and light effects on epilithon. We also sampled 18 sites across Trinidad's Northern Range Mountains once each in a wet and dry season to examine the effects of naturally occurring differences in light and dissolved nutrient availability on epilithic characteristics. We found greater chlorophyll $a$ concentrations in habitats with greater light availability, but the effect of light on epilithon stoichiometry differed between the site-survey and focal-tributary data. In general, epilithic C:nutrient ratios decreased with increasing dissolved nutrient concentrations, but relationships between nutrient availability and biomass probably were obscured by naturally high dissolved $\mathrm{N}$ and $\mathrm{P}$ concentrations in many of the streams. Season and habitat type had profound effects on epilithon variables. Biomass and \% C generally decreased in riffles and under wetseason conditions. These results suggest multiple controls for the quantity and quality of stream epilithon and have important implications for in-stream consumers.
\end{abstract}

Key words: streams, light:nutrient hypothesis, periphyton, algae, disturbance, Trinidad.

\footnotetext{
${ }^{6}$ Present address: University of Colorado, Institute of Arctic and Alpine Research, Boulder, Colorado 80303 USA. E-mail: tyler.j.kohler@gmail.com

7 E-mail address: heatherly1975@gmail.com

${ }^{8}$ Present address: University of Victoria, Department of Biology, Victoria, British Columbia, Canada V8W 3N5. E-mail: rana@uvic.ca

${ }^{9}$ Present address: Universidade do Estado do Rio de Janeiro, Departamento de Ecologia, Rio de Janeiro, Rio de Janeiro 20550-013 Brazil. E-mail: eugenia.zandona@gmail.com

${ }^{10}$ E-mail addresses: drmikemarshall@gmail.com

11 asf3@cornell.edu

12 cpringle@uga.edu

13 gupy@ucr.edu

14 sthomas5@unl.edu
}

Ecological stoichiometry is the study of the mass balance of essential elements as they cycle through the biosphere (Sterner and Elser 2002). Investigators have applied a stoichiometric framework to gain insight into evolution (Jeyasingh and Weider 2007), population dynamics (Nakazawa 2011), trophic interactions (Dickman et al. 2008), and ecosystem function (Sterner and Elser 2002, Schade et al. 2005). Epilithon is a rockbound biofilm comprising algae, fungi, bacteria, extracellular exudates, and detritus. It is an important basal resource in streams, and its elemental composition is plastic (Sterner and Elser 2002, reviewed by Cross et al. 2005). Algae constitute only a portion of biofilm assemblages, but shifts in algal nutrient quality affect epilithon stoichiometry as a whole, even when algae are at low densities (Frost et al. 2005). Nutrient imbalances often arise between grazing 
macroinvertebrates and their food resources because of algal stoichiometric plasticity. These imbalances have consequences for foodweb structure and nutrient cycling (Dickman et al. 2008, Small and Pringle 2010).

Light availability controls epilithon community composition, quantity, and quality. Increasing light availability often leads to increased algal biomass (e.g., Sanches et al. 2011) and higher C:nutrient ratios because of increased $\mathrm{C}$ fixation relative to nutrient acquisition (Sterner et al. 1997, Sterner and Elser 2002, Dickman et al. 2006). Phytoplankton adapted to lowlight environments have higher chloroplast densities and elevated chlorophyll concentrations relative to those adapted to high-light environments (Geider et al. 1998, reviewed by Arrigo 2005). Chlorophyll has relatively high $\mathrm{N}$ and low $\mathrm{P}$ content, so greater intracellular chlorophyll concentrations lead to higher $\mathrm{N}: \mathrm{P}$ ratios in low-light-adapted cells relative to those growing under high-light conditions (Geider et al. 1998, reviewed by Arrigo 2005). P content of algae also may increase at low light levels because of increased phospholipid production resulting from photoacclimation (Dickman et al. 2006).

Nutrient availability strongly affects epilithon stoichiometry (Sterner and Elser 2002) and biomass (Kohler et al. 2011), but above certain concentrations, nutrients may no longer stimulate primary production in streams (Newbold 1992). Algal cells assimilate $\mathrm{N}$ and $\mathrm{P}$ in excess of their metabolic requirements when nutrient concentrations are high, presumably as a means of coping with variable resource availability (Sterner and Elser 2002, Dodds and Whiles 2010). As a result, epilithon nutrient content can increase in response to increasing nutrient concentrations, thereby causing C:nutrient ratios to decline (Fanta et al. 2010, Small and Pringle 2010, Kohler et al. 2011). Stream nutrient concentrations vary with local and regional vegetation patterns, geologic conditions, and a suite of human activities in watersheds (Carpenter et al. 1998, Kemp and Dodds 2001, Neill et al. 2001, Wetzel 2001). Combined, these factors create considerable heterogeneity in nutrient concentrations across streams in relatively close proximity to one another.

Spatial and temporal heterogeneity of light and nutrients create a diverse resource template across which nutrient limitation and algal stoichiometry can vary (Hill et al. 2011). The Light:Nutrient Hypothesis (LNH; Sterner et al. 1997) predicts that epilithon nutrient content will increase with increasing nutrient availability and decrease with increasing light availability as a result of the mechanisms outlined above. Most tests of the LNH have been restricted to lentic (Hillebrand et al. 2004, Dickman et al. 2006, Sanches et al. 2011) or artificial habitats/substrata (Fanta et al.
2010, Guariento et al. 2011, Hill et al. 2011) and have provided mixed support for LNH predictions (Hill and Fanta 2008, Hill et al. 2009, Liess et al. 2009). Thus, considerable uncertainty exists regarding how light and nutrients interact to shape epilithon properties.

In lotic ecosystems, high and low flows have the potential to alter ecosystem structure and function profoundly through scour and accrual of epilithon (Biggs and Thomsen 1995, Dodds et al. 1996, Francoeur and Biggs 2006). Variation in discharge and flow velocity influence the flux of nutrients to epilithic communities (Dodds and Biggs 2002) and shape algal community structure (Biggs et al. 1998, Francoeur and Biggs 2006). By extension, it is reasonable to predict that flow also affects epilithon stoichiometry, and if so, both spatial and temporal variation in flow should be taken into consideration when assessing epilithon communities in natural streams. Spatial variation can be manifested in differences between pools and riffles, which have very different benthic flow characteristics. In tropical streams, temporal variation may result from distinct wet-dry seasons (Wantzen et al. 2006), providing a unique opportunity to investigate how habitat and seasonality combine to influence epilithon biomass and stoichiometry.

We examined how epilithon is influenced by light, nutrients, and flow in Neotropical streams. Specifically, we: 1) conducted a 2-y experiment in 4 focal streams to assess the effects of flow variability and manipulated canopy cover on epilithon biomass, chlorophyll $a$, and stoichiometry and 2) sampled 18 sites in Trinidad's Northern Mountain Range to examine the effects of natural gradients of light availability and dissolved nutrient concentrations on epilithon characteristics. Based on the $\mathrm{LNH}$, we predicted that increased light availability would result in epilithon with greater C:nutrient ratios and lower N:P because of increased photosynthetic rates and lower intracellular chlorophyll $a$ concentrations (Sterner et al. 1997). We also expected C:nutrient ratios to decrease with greater nutrient concentrations in the water column because of alleviation of limitation (Hillebrand and Kahlert 2001). Last, we predicted that epilithon biomass and C:nutrient ratios should decrease in the wet season because of more frequent scouring, which would decrease the relative amount of detritus associated with epilithon.

\section{Methods}

\section{Study sites}

We worked in the Northern Range of Trinidad, West Indies, and used 2 field approaches. First, we quantified temporal trends in epilithon stoichiometry 


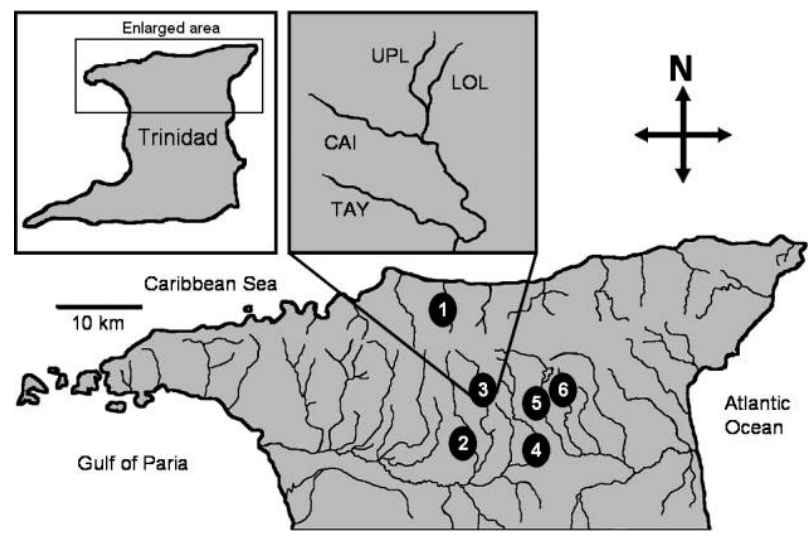

FIG. 1. Map of drainages sampled in the Northern Range of Trinidad ( $1=$ Marianne, $2=$ Arima, $3=$ Guanapo, $4=$ Aripo, 5 = Quare, 6 = Turure). Top center is detail of Heights of Guanapo from the Guanapo drainage, which contains the 4 focal sites (Lower La Laja = LOL, Upper La Laja $=$ UPL, Taylor $=$ TAY, and Caigual $=\mathrm{CAI})$.

and biomass in 4 first-order streams in the Guanapo drainage: Lower La Laja (LOL), Upper La Laja (UPL), Taylor (TAY), and Caigual (CAI) (Fig. 1). These 4 headwater streams, collectively termed focal streams, are relatively undisturbed, although they drain small areas of active and inactive citrus, coffee, and cocoa plantations (Helson et al. 2006) and are similar in geology and floral communities. We sampled streams every other month from September 2007 to September 2009. In July 2007 and July 2008, we experimentally thinned riparian canopies at UPL (4\% canopy reduction) and TAY (28\% canopy reduction) to create elevated light conditions. We maintained canopy treatments throughout the sampling period.

Second, we surveyed 18 stream sites from 6 river basins in Trinidad's Northern Range (Fig. 1). These streams represented a broad range of natural canopy cover and nutrient concentrations. Thus, we were able to examine the effects of light and nutrients on epilithon biomass and stoichiometry across larger gradients than existed in focal streams. Three of these drainages, the Turure, Quare, and Aripo, have prominent $\mathrm{CaCO}_{3}$ formations (tufa; see Day and Chenoweth 2004), and consequently have low natural concentrations of soluble reactive P (SRP; $<10 \mu \mathrm{g} / \mathrm{L}$ ) caused by $\mathrm{Ca}-\mathrm{P}$ precipitation, but varying levels of dissolved inorganic N (DIN). The Arima and Guanapo Rivers have relatively high DIN and SRP concentrations from natural processes (Guanapo) and agricultural activity (Arima). In contrast, the Marianne River system is relatively pristine (Helson et al. 2006) with low levels of DIN and SRP. In each of the 6 basins, we sampled epilithon from headwaters (UP), midreaches (MD), and downstream (DN) reaches to examine natural canopy effects. We sampled once in the wet season (June-December) and once in the dry season (January-May) to evaluate seasonal differences. The Turure, Arima, and Quare rivers were sampled in July 2008 (wet season) and March 2009 (dry season), whereas the Aripo, Marianne, and Guanapo were sampled in July 2007 and March 2009.

\section{Sampling procedure}

Focal streams.-In each focal stream, we established 3 transects 30 to $50 \mathrm{~m}$ apart, and sampled epilithon from pools and riffles separately along each transect on each date. We took $\geq 5$ samples at randomly chosen locations in each habitat with a modified Loeb sampler (Loeb 1981), which is a cylinder $\left(5.07 \mathrm{~cm}^{2}\right)$ with a brush-fitted plunger, to remove epilithon from substrata. We combined all samples from a single habitat type into a single slurry and kept slurries in a cooler until they could be processed that evening. At each transect, we measured canopy cover periodically with a hemispherical densiometer (method of Lemmon 1956), and we measured light continuously with Hobo $^{\circledR}$ light loggers (Onset Computer Corp., Bourne, Massachusetts). We used conversions provided by Thimijan and Heins (1983) to convert lux to moles quanta $\mathrm{m}^{-2} \mathrm{~d}^{-1}$ and averaged daily totals for each stream for each month. In August 2008, a major flood carried away many of our light loggers, some of which were not recovered. For UPL and LOL, we averaged the available values from 2008 to substitute for missing data (May-August 2008). For CAI, we averaged later values because no previous data were available. We are confident that values were comparable based on densiometer estimates and historical trends. For TAY, we lost all prethinning light values, so we were unable to use previous or subsequent data. However, we placed loggers in the unthinned reach immediately below the experimental site in April 2009 and used these data to estimate light conditions before the canopy was reduced. We based flow measurements on stage, which was measured at the bottom of the LOL reach with a Solinst pressure transducer (Solinst Canada, Georgetown, Ontario) every $30 \mathrm{~min}$.

Site survey.-We established 10 transects 10 to $20 \mathrm{~m}$ apart at each survey site. We alternately sampled pool and riffle habitats, resulting in 5 pool and 5 riffle samples per site per season. In 2008 and 2009, we sampled epilithon at each transect by scrubbing the tops of 3 rocks with a toothbrush to yield a single aggregated slurry for each transect. We traced the outline of each rock onto waterproof paper and calculated rock surface area in the laboratory. At 
streams sampled in the wet season of 2007 and at the MD Turure site where loose rocks were not present because of carbonate precipitation, we collected pool and riffle samples with a Loeb sampler as explained above. Loeb samplers yielded higher estimates of ashfree dry mass (AFDM) and chlorophyll $a$ than rock scrapings (TJK, unpublished data), so we used only stoichiometric data from Loeb samples. Last, we used a densiometer to estimate \% canopy cover at each sampling site, and we used the method of Gore (2006) to estimate stream discharge.

\section{Epilithon processing}

We took quantitative subsamples from each epilithon slurry to estimate chlorophyll $a$, AFDM, and $\mathrm{C}: \mathrm{N}: \mathrm{P}$ stoichiometry. We filtered chlorophyll $a$ subsamples through precombusted 25-mm GF/F filters and froze the filters until analysis. Within $30 \mathrm{~d}$ of sampling, we extracted samples in $90 \%$ reagent-grade ethanol for $24 \mathrm{~h}$ in the dark. We used an Aquafluor handheld fluorometer (Turner Designs, Sunnyvale, California) to estimate active chlorophyll $a$ and corrected for phaeophytin (Parsons et al. 1984). We collected a $2^{\text {nd }}$ subsample for estimation of AFDM on a preweighed, precombusted 47-mm GF/F filter. We combusted the subsample in a muffle furnace at $500^{\circ} \mathrm{C}$ and reweighed to calculate $\mathrm{AFDM} / \mathrm{m}^{2}$. We divided chlorophyll $a$ values by corresponding AFDM values to create an alternative formulation of the autotrophic index (AI), which is an indicator of trophic state (Flotemersch et al. 2006).

We dried subsamples for C:N:P analysis in an oven at $50-55^{\circ} \mathrm{C}$ and ground them to a fine powder. We measured $\mathrm{C}$ and $\mathrm{N}$ content with a COSTECH Analytical ECS 4010 Elemental Analyzer (Costech Analytical Technologies, Valencia, California) and corrected for inorganic $\mathrm{C}$ with a fumigation method similar to that used by Hedges and Stern (1984). We combusted the $\mathrm{P}$ subsample in a muffle furnace at $500^{\circ} \mathrm{C}$ for $1 \mathrm{~h}$, digested it with $1 \mathrm{~N} \mathrm{HCl}$, and analyzed it as for SRP (Murphy and Riley 1962) with a Cary 100 UV-visible spectrophotometer (Agilent Technologies, Palo Alto, California). The resulting values were then converted to molar $\mathrm{C}: \mathrm{N}, \mathrm{C}: \mathrm{P}$, and $\mathrm{N}: \mathrm{P}$ ratios.

\section{Nutrients}

We collected stream water for water chemistry analyses on each sampling date at focal and survey streams. We used an Aquafluor handheld fluorometer to measure $\mathrm{NH}_{4}{ }^{+}$immediately by the method of Holmes et al. (1999) as modified by Taylor et al. (2007). We quantified $\mathrm{NO}_{3}{ }^{-}$and $\mathrm{NO}_{2}{ }^{-}$with a Dionex ICS-90 Ion Chromatography System equipped with a
Dionex Automated Sampler and Chromeleon software (Dionex Corporation, Sunnyvale, California). $\mathrm{NO}_{2}{ }^{-}$was never detectable in samples $(<5 \mu \mathrm{g} / \mathrm{L})$. Therefore, we calculated DIN as the sum of $\mathrm{NH}_{4}{ }^{+}$and $\mathrm{NO}_{3}{ }^{-}$. We measured SRP with the method developed by Murphy and Riley (1962) on a Pharmacia LKB Ultraspec III spectrophotometer (model: 80-2097-62; Pharmacia Biotech, Uppsala, Sweden) with a detection limit of $1.5 \mu \mathrm{g} / \mathrm{L}$.

\section{Statistical analysis}

Prior to analyses, we conducted an exploratory data analysis (Zuur et al. 2010) to identify potential outliers, lack of variance homogeneity, and temporal independence. We $\log _{10}(x)$-transformed all variables that were not normally distributed to satisfy the assumption of normality. We used generalized least squares (GLS) regression models to analyze epilithon chlorophyll $a$, AFDM, AI, and molar nutrient ratios because this method allowed us to account for heterogeneity of variances among levels and for temporal autocorrelation in the focal-stream data (Pinheiro and Bates 2001).

The global model (i.e., models with all explanatory variables) for both the focal and survey streams had fixed effects that included stream identity, habitat (pool or riffle), season (wet or dry), and dissolved nutrients $\left(\mathrm{NH}_{4}{ }^{+}, \mathrm{NO}_{3}{ }^{-}\right.$, and SRP). We included light in the model as photosynthetically active radiation (PAR) for focal streams and as \% open canopy for survey streams. In our analysis of the focal stream reaches, we also included the number of days since stage increases (flow events) of different sizes to examine the effect of flow and associated scour on epilithon characteristics. In cases where multiple flow magnitudes were significant, the final model included the flow condition that produced the lowest Akaike Information Criterion (AIC) value. Occasionally, variation differed between streams or habitats. Therefore, we used the varIdent variance structure in our GLS regressions to allow levels to vary independently within categorical variables, thereby avoiding violation of assumptions of homogeneity of variance (Zuur et al. 2009). Last, we used an autoregressive moving average (ARMA) serial correlation structure for our focal site data to remove temporal nonindependence by modeling each date as a function of previous dates (Zuur et al. 2009).

We investigated optimal model structure for each variable by using restricted maximum likelihood (REML) on global models to test for the best combination of random effects (i.e., variance and correlation structures), followed by maximum likeli- 
TABLE 1. Minimum adequate generalized least squares models for epilithon variables in focal streams (see Fig. 1 for stream names). $\mathrm{df}=$ degrees of freedom, $L$-ratio $=\log$ likelihood ratio, $\mathrm{vf}=$ variance function, $\mathrm{AFDM}=$ ash-free dry mass, $\mathrm{AI}=$ autotrophic index, $\mathrm{SRP}=$ soluble reactive $\mathrm{P}$, since. $8=$ days since an 8 -cm increase in stream stage, since.16 = days since a $16-\mathrm{cm}$ increase in stream stage.

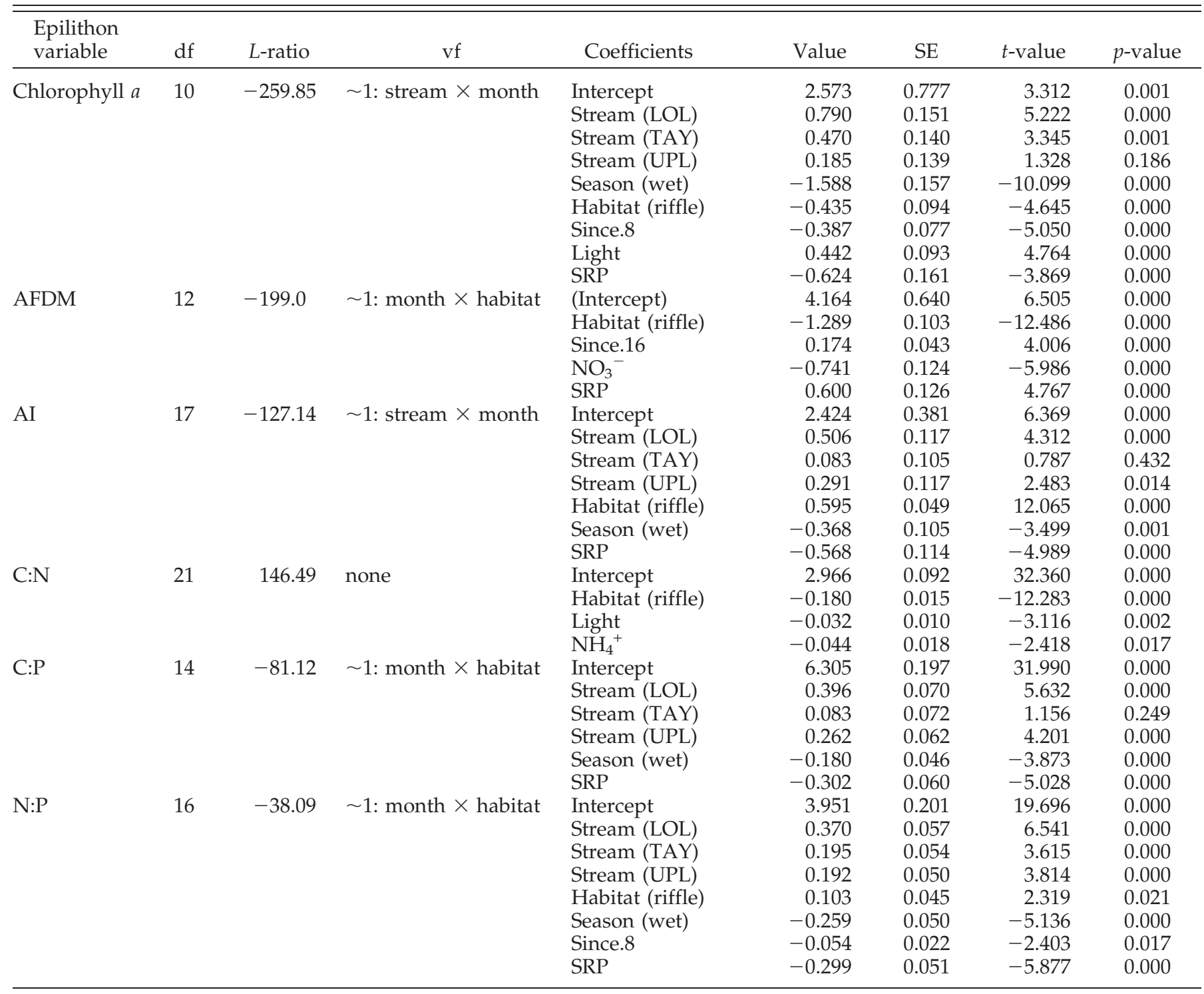

hood (ML) for fixed effects (Diggle et al. 2002). Model improvement was assessed based on a reduction in the AIC value for a given model and likelihood ratio (L-ratio) tests (Quinn and Keough 2002). Once we had created GLS models and assessed structure, we refined models by eliminating nonsignificant terms (i.e., backward selection) using ML to retrieve the minimum adequate model and used REML to report final models (West et al. 2006). We conducted an $L$ ratio test with ML to identify significance of individual variables. This test compared the minimum adequate model with the same model without the given variable. We set significance at $\alpha=0.05$. We ran all statistical analyses with the nlme package (Pinheiro et al. 2006) in $\mathrm{R}$ (version 2.9.2; R Development Core Team, Vienna, Austria). The complete output for the full models is presented in Table 1 for the focal streams and Table 2 for the survey streams.

\section{Results}

Focal streams

Light, stage, and dissolved nutrients.-Scouring flow events were more frequent during the wet season, with fewer days between events raising stream stage $\geq 8 \mathrm{~cm}(t$-test, $t=16.81, p<0.001)$ or $16 \mathrm{~cm}(t$-test,$t=$ 
TABlE 2. Minimum adequate generalized least squares models for epilithon variables in survey streams (see Fig. 1 for drainages). Chlorophyll $a$, ash-free dry mass (AFDM), and autotrophic index (AI) values from samples collected with Loeb samplers were excluded (see text for explanation). $\mathrm{df}=$ degrees of freedom, $L$-ratio $=\log$ likelihood ratio, $\mathrm{vf}=\mathrm{variance}$ function, $\mathrm{SRP}=$ soluble reactive $\mathrm{P}$.

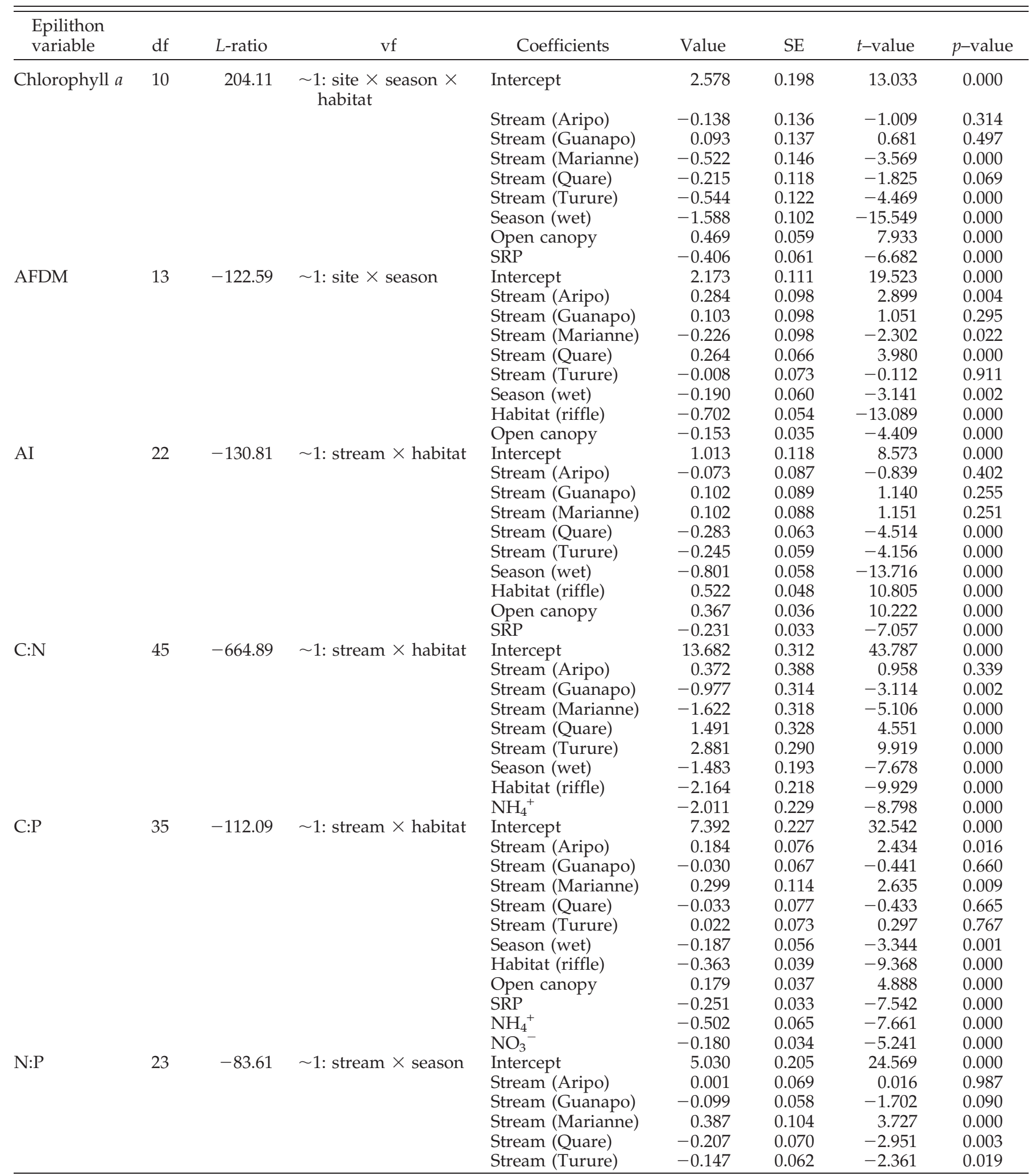


TABle 2. Continued.

\begin{tabular}{|c|c|c|c|c|c|c|c|c|}
\hline $\begin{array}{l}\text { Epilithon } \\
\text { variable }\end{array}$ & $\mathrm{df}$ & $L$-ratio & $\mathrm{vf}$ & Coefficients & Value & SE & $t$-value & $p$-value \\
\hline & & & & Season (wet) & -0.108 & 0.050 & -2.147 & 0.033 \\
\hline & & & & Open canopy & 0.127 & 0.035 & 3.661 & 0.000 \\
\hline & & & & SRP & -0.172 & 0.028 & -6.193 & 0.000 \\
\hline & & & & $\mathrm{NH}_{4}^{+}$ & -0.452 & 0.061 & -7.427 & 0.000 \\
\hline & & & & $\mathrm{NO}_{3}^{-}$ & -0.217 & 0.033 & -6.662 & 0.000 \\
\hline
\end{tabular}

16.22, $p<0.001$ ) than during the dry season (Fig. 2). DIN and SRP concentrations ranged from 76 to 382 and from 10 to $68 \mu \mathrm{g} / \mathrm{L}$, respectively (Fig. 3A, B). $\mathrm{NH}_{4}{ }^{+}(t$-test, $t=3.99, p<0.001)$ and SRP $(t$-test, $t=$ 6.78, $p<0.001)$ concentrations were greatest in the dry season in all focal streams, but $\mathrm{NO}_{3}{ }^{-}$concentrations did not differ between seasons. As a result, DIN:SRP ratios were generally greater in the wet than in the dry season, but this relationship was not statistically significant. Fluxes of PAR were greater at streams with experimentally thinned canopies than at control streams. Thinning increased fluxes in UPL by $30 \%$ and TAY by $800 \%$ on average (Fig. 3C).

Epilithon biomass and stoichiometry.-Chlorophyll a was positively related to PAR $(L$-ratio $=22.49, \mathrm{df}=9$, $p<0.001)$, negatively related to SRP concentrations $(L$-ratio $=15.07, \mathrm{df}=9, p<0.001)$ and days since a $\geq 8$-cm increase in stage $(L$-ratio $=25.14, \mathrm{df}=9, p<$ $0.001)$, and differed among streams ( $L$-ratio $=28.08$, $\mathrm{df}=7, p<0.001)$. Chlorophyll $a$ was lower in riffles than in pools $(L$-ratio $=21.43, \mathrm{df}=9, p<0.001)$ and in the wet than in the dry season $(L$-ratio $=87.81, \mathrm{df}=9$, $p<0.001$ ) (Fig. 4A). AFDM increased with SRP concentrations ( $L$-ratio $=19.99, \mathrm{df}=11, p<0.001$ ) and with days since a $16-\mathrm{cm}$ increase in stage ( $L$-ratio

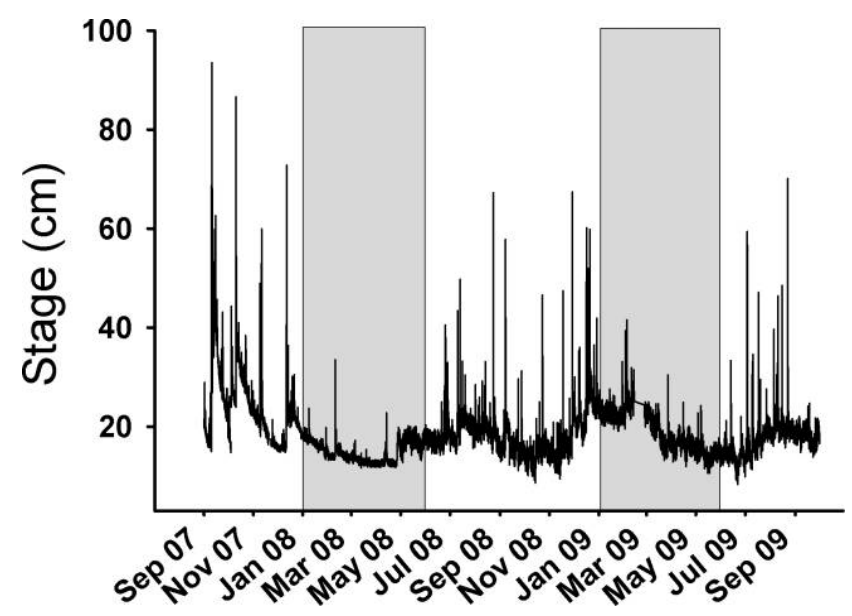

FIG. 2. Stage measured at the bottom of Lower La Laja (a focal site) throughout the study period. Grey bars indicate dry-season months.
$=13.81, \mathrm{df}=11, p<0.001)$ and decreased with increasing $\mathrm{NO}_{3}{ }^{-}$concentration ( $L$-ratio $=25.86, \mathrm{df}=$ $11, p<0.001)$. AFDM was lower in riffles than in pools $(L$-ratio $=84.24, \mathrm{df}=11, p<0.001$; Fig. $4 \mathrm{~B})$. AI differed among streams ( $L$-ratio $=23.15, \mathrm{df}=14, p<$ 0.001 ) and was negatively related to SRP concentration $(L$-ratio $=17.42, \mathrm{df}=16, p<0.001)$. AI was greater in riffles than in pools ( $L$-ratio $=89.81, \mathrm{df}=$ $16, p<0.001)$ and was lower in the wet than in the dry season $(L$-ratio $=11.24, \mathrm{df}=16, p<0.001)$ (Fig. $4 \mathrm{C})$.

C:N of epilithon was lower in riffles than in pools $(L$-ratio $=67.82, \mathrm{df}=20, p<0.001 ;$ Fig. $4 \mathrm{D})$ and was negatively related to PAR $(L$-ratio $=7.34, \mathrm{df}=20, p=$ 0.007 ) and $\mathrm{NH}_{4}{ }^{+}$concentration ( $L$-ratio $=4.77, \mathrm{df}=$ 20, $p=0.029$; Fig. 5A). C:P (L-ratio $=39.51, \mathrm{df}=11$, $p<0.001)$ and $\mathrm{N}: \mathrm{P}(L$-ratio $=37.77, \mathrm{df}=13, p<0.001)$ differed among streams. C:P was lower in the wet than in the dry season ( $L$-ratio $=12.80, \mathrm{df}=13, p<$ 0.001; Fig. 4E) and was negatively related to SRP concentration $(L$-ratio $=22.08, \mathrm{df}=13, p<0.001$; Fig. 5B). N:P was higher in riffles than in pools ( $L-$ ratio $=4.42, \mathrm{df}=15, p=0.036)$ and lower in the wet than in the dry season $(L$-ratio $=21.98, \mathrm{df}=15, p<$ 0.001 ) (Fig. $4 \mathrm{~F}$ ), and negatively related to SRP concentration $(L$-ratio $=27.30, \mathrm{df}=15, p<0.001$; Fig. $5 \mathrm{C})$ and days since an $8-\mathrm{cm}$ increase in stage (L-ratio = $0.024, \mathrm{df}=15, p=0.024$ ).

\section{Site survey}

Dissolved nutrients and canopy cover.-Water chemistry was strongly influenced by basin and stream position (i.e., UP, MD, DN) (Fig. 6A, B). Nutrient concentrations varied seasonally. SRP concentrations were significantly greater in the dry than in the wet season ( $t$-test, $t=4.86, p<0.001$ ), and $\mathrm{NH}_{4}{ }^{+}$ concentrations were greater in the wet than in the dry season ( $t$-test, $t=-4.8853, p<0.001)$. However, $\mathrm{NO}_{3}{ }^{-}$concentrations did not differ between seasons. Consequently, molar DIN:SRP was greater in the wet than in the dry season. DN sites had the most open canopies (Fig. 6C) and greatest discharges, averaging $25 \%$ open canopy and $326 \mathrm{~L} / \mathrm{s}$, respectively. MD and UP sites were similar, with mean \% open canopy of 


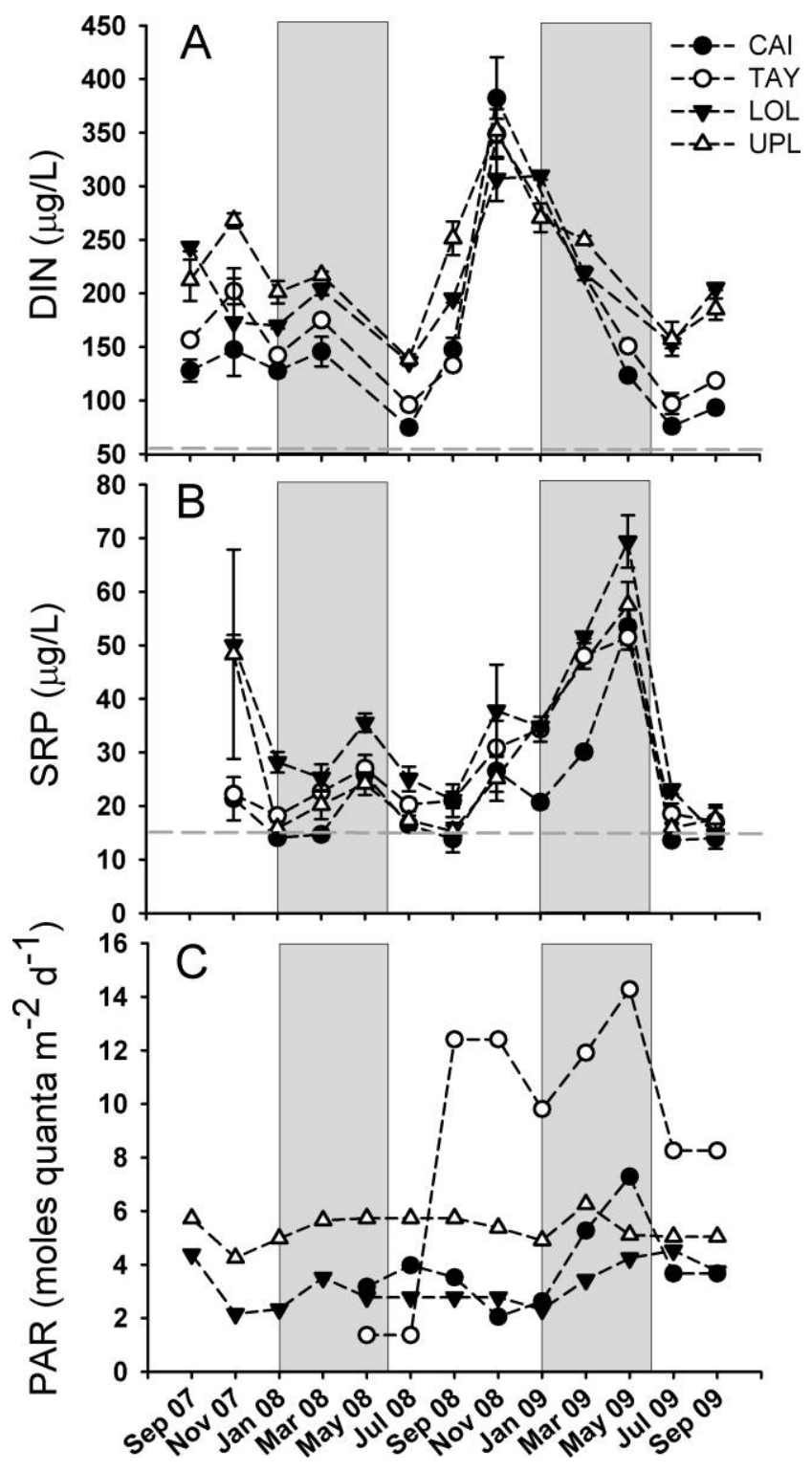

FIG. 3. Mean ( $\pm 1 \mathrm{SE})$ dissolved inorganic N (DIN) (A), soluble reactive $\mathrm{P}(\mathrm{SRP})(\mathrm{B})$, and the average daily total photosynthetically active radiation (PAR) (averaged over each sampled month) (C) for the 4 focal streams. Canopy was thinned at UPL in July 2007 and at TAY in July 2008. Dotted lines indicate predicted concentrations of epilithon saturation for DIN and SRP (Newbold 1992). Grey bars indicate dry-season months. See Fig. 1 for site codes.

8.4 and $7.0 \%$ and mean discharge of 43.4 and $35.7 \mathrm{~L} / \mathrm{s}$, respectively.

Epilithon biomass and stoichiometry.-Chlorophyll $a$ differed among streams $(L$-ratio $=30.77, \mathrm{df}=5, p<$ 0.001 ) and was negatively related to SRP concentration $(L$-ratio $=42.46, \mathrm{df}=9, p<0.001)$, positively related to \% open canopy ( $L$-ratio $=57.93, \mathrm{df}=9, p<$ $0.001)$, and was lower in the wet than in the dry season $(L$-ratio $=172.98, \mathrm{df}=9, p<0.001 ;$ Fig. 7A, B $)$. AFDM differed among streams $(L$-ratio $=40.69, \mathrm{df}=$ $8, p<0.001)$, was lower in the wet than in the dry season $(L$-ratio $=9.223, \mathrm{df}=12, p=0.002)$ and in riffles than in pools $(L$-ratio $=117.69, \mathrm{df}=12, p<$ 0.001) (Fig. 7C, D), and decreased with \% open canopy $(L$-ratio $=15.95, \mathrm{df}=12, p<0.001)$. AI differed among streams $(L$-ratio $=34.16, \mathrm{df}=17, p<$ $0.001)$ and was lower in the wet than in the dry season $(L$-ratio $=90.58, \mathrm{df}=21, p<0.001)$ and higher in riffles than in pools ( $L$-ratio $=76.41, \mathrm{df}=21, p<$ 0.001) (Fig. 7E, F). AI was negatively related to SRP concentration $(L$-ratio $=37.11, \mathrm{df}=21, p<0.001)$ and increased with \% open canopy $(L$-ratio $=65.10, \mathrm{df}=$ $21, p<0.001)$.

$\mathrm{C}: \mathrm{N}$ was lower in riffles than in pools ( $L$-ratio $=$ 46.22, $\mathrm{df}=44, p<0.001)$ and lower in the wet than in the dry season $(L$-ratio $=35.54, \mathrm{df}=44, p<0.001)$ (Fig. 7G, H). C:N differed among streams ( $L$-ratio = 90.67, $\mathrm{df}=40, p<0.001)$ and was negatively related to $\mathrm{NH}_{4}{ }^{+}$concentrations $(L$-ratio $=29.21, \mathrm{df}=44, p<$ 0.001; Fig. 5D). C:P was lower in riffles than in pools $(L$-ratio $=50.87, \mathrm{df}=34, p<0.001)$ and in the wet than in the dry season ( $L$-ratio $=8.10, \mathrm{df}=34, p=$ 0.004; Fig. 7I, J). C:P differed among streams (L-ratio $=16.89, \mathrm{df}=30, p=0.005)$, increased with \% open canopy (L-ratio $=10.98, \mathrm{df}=34, p<0.001)$, and decreased with $\mathrm{NH}_{4}{ }^{+}(L$-ratio $=27.00, \mathrm{df}=34, p<$ $0.001), \mathrm{NO}_{3}{ }^{-}(L$-ratio $=18.87, \mathrm{df}=34, p<0.001)$, and SRP $(L$-ratio $=36.27, \mathrm{df}=34, p<0.001$; Fig. 5E) concentrations. In pools, N:P was higher in the wet than in the dry season (Fig. 7K, L). However, the wet season had a negative effect on modeled epilithon N:P $(L$-ratio $=4.13, \mathrm{df}=22, p=0.042) . \mathrm{N}: \mathrm{P}$ differed among streams $(L$-ratio $=39.01, \mathrm{df}=18, p<0.001)$, was positively related to $\%$ open canopy $(L$-ratio $=$ $8.12, \mathrm{df}=22, p=0.004)$, and was negatively related to $\mathrm{NH}_{4}{ }^{+}(L$-ratio $=29.22, \mathrm{df}=22, p<0.001), \mathrm{NO}_{3}{ }^{-}(L-$ ratio $=31.08, \mathrm{df}=22, p<0.001)$, and SRP (L-ratio $=$ 24.55, $\mathrm{df}=22, p<0.001$; Fig. 5F) concentrations.

\section{Discussion}

Light, nutrients, and flow significantly affected epilithon biomass and stoichiometry in Trinidadian streams. Greater chlorophyll a concentrations were associated with higher light levels as predicted, but the relationship between light and epilithon stoichiometry was not consistent between focal and survey streams. Nutrient content of epilithon was significantly greater in streams with greater dissolved nutrients. However, we did not detect strong relationships between nutrients and epilithon biomass, possibly because of light limitation, varying 


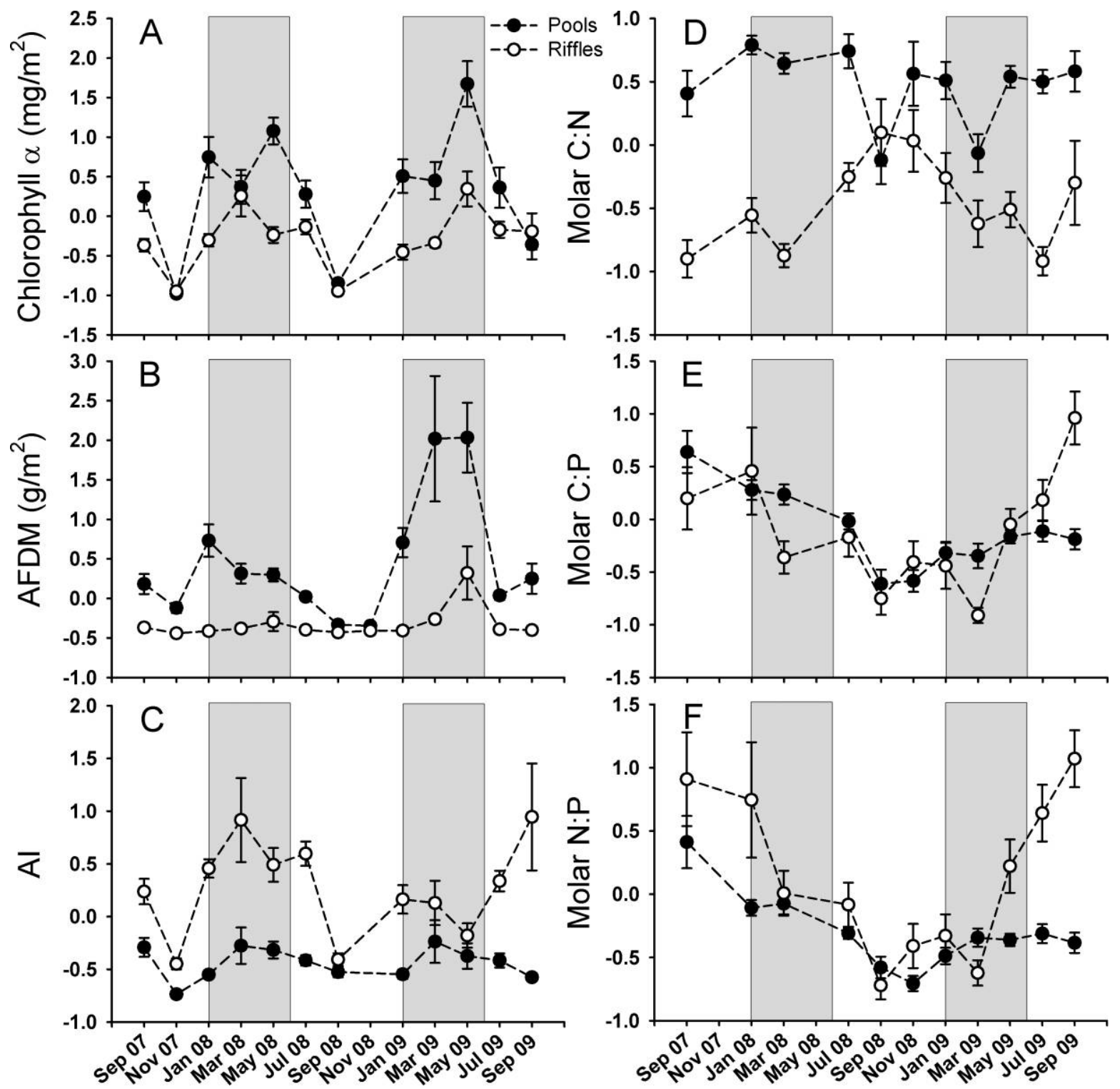

FIG. 4. Mean ( \pm 1 SE) $z$-transformed focal-stream epilithon chlorophyll $a$ (A), ash-free dry mass (AFDM) (B), autotrophic index (AI) (C), molar C:N (D), C:P (E), and N:P (F) averaged by pool and riffle habitats. Grey bars indicate dry-season months. $z-$ transformations defined by $z=(X-\bar{X}) / S D$.

periods between sampling times and scouring flows, or high nutrient availability at some locations. Our data suggest that epilithon communities in these Neotropical streams are influenced by numerous factors that structure epilithon biomass and affect their stoichiometry differentially through space and time.

\section{Flow regime, habitat, and epilithon variability}

Tropical streams are characterized by relatively consistent irradiance and temperature, which potentially enable epilithic growth throughout the year.
However, seasonal changes in flow could strongly affect the benthic ecology of these systems. Flow can be an important factor controlling algal biomass in temperate streams (Biggs and Close 1989, Dodds et al. 1996, Francoeur et al. 1998), and flow variables (wet/ dry seasons, days since flow events) were strong predictors of epilithon dynamics in our study. Congruent with our predictions, epilithon AFDM was almost always greater when sampled following a period of relatively stable flow conditions or in habitats with reduced flow velocity (dry seasons and pool habitats, respectively) than during or soon after periods of high flow or in riffles. Wet-season flow 

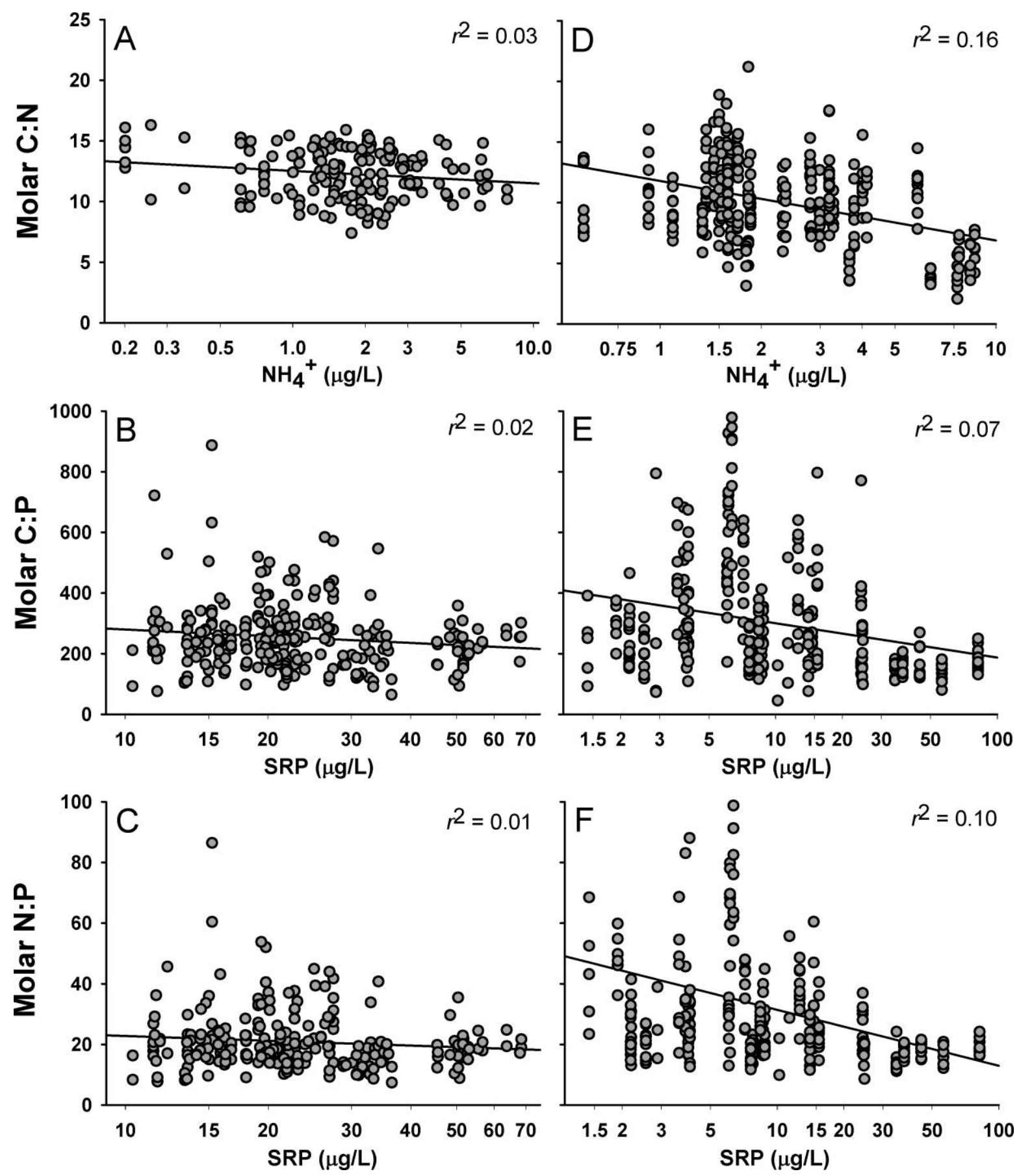

FIG. 5. Simple linear regressions for molar $\mathrm{C}: \mathrm{N}$ vs log-transformed $\mathrm{NH}_{4}{ }^{+}$concentration (A, D), molar C:P vs log-transformed soluble reactive $\mathrm{P}(\mathrm{SRP})(\mathrm{B}, \mathrm{E})$, and molar N:P vs log-transformed SRP $(\mathrm{C}, \mathrm{F})$ at focal $(\mathrm{A}, \mathrm{B}, \mathrm{C})$ and survey $(\mathrm{D}, \mathrm{E}, \mathrm{F})$ streams.

conditions reduced AFDM in pool habitats to levels observed year-round in riffle habitats. In contrast, chlorophyll $a$ decreased with increasing days since an $8-\mathrm{cm}$ increase in stage. This result might have been caused by accumulation of fine detritus and associated shading of epilithic algae during low-flow periods or by increased foraging by invertebrate grazers and fish, but our data do not permit us to discriminate between these potential mechanisms.

Season and habitat type affected epilithon nutrient ratios in focal and survey streams. All epilithon nutrient ratios except focal-stream $\mathrm{C}: \mathrm{N}$ were lower in the wet than in the dry season, and focal- and survey-stream C:N and survey-stream C:P were lower 

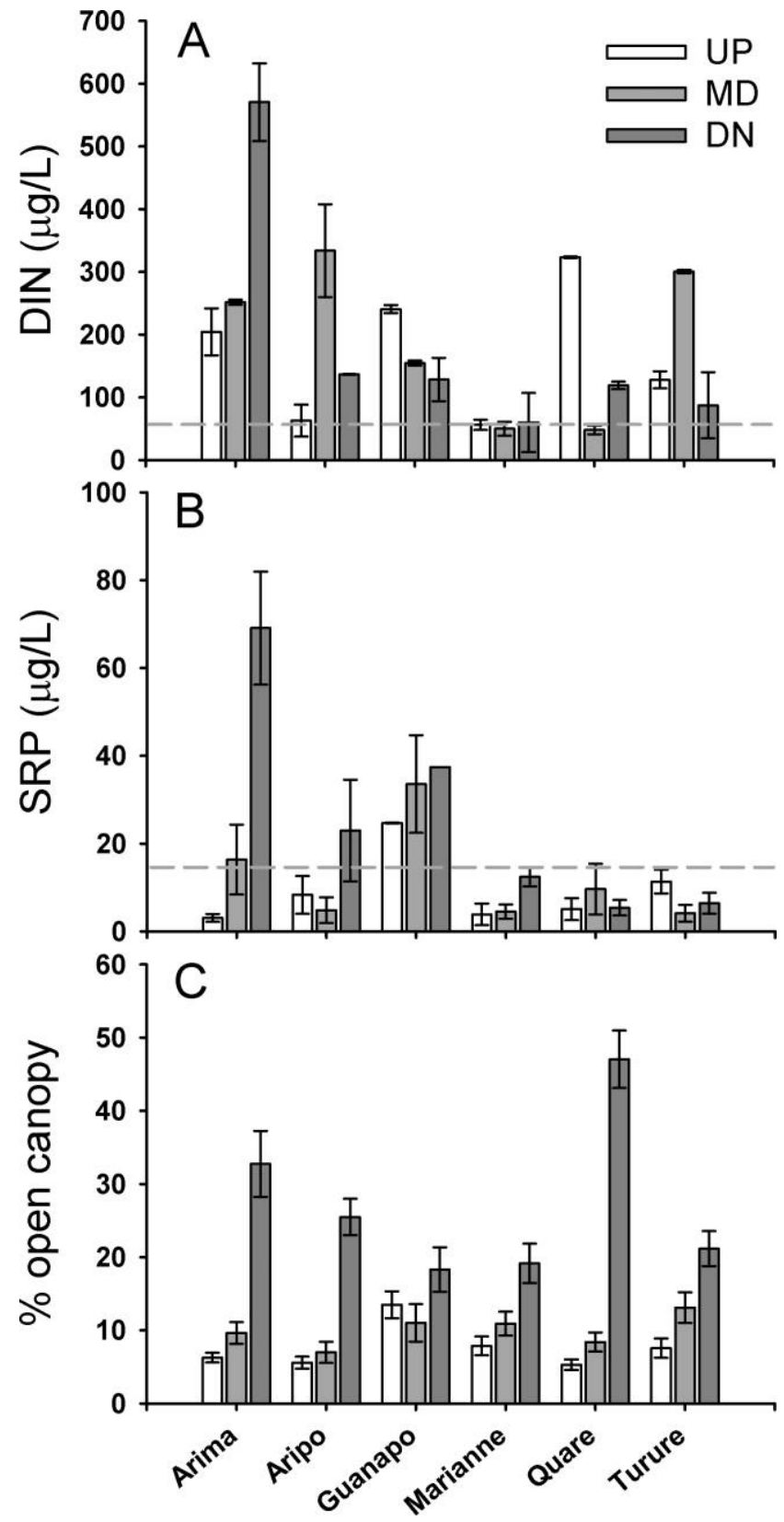

FIG. 6. Mean ( $\pm 1 \mathrm{SE})$ dissolved inorganic N (DIN) (A), soluble reactive $\mathrm{P}(\mathrm{SRP})(\mathrm{B})$, and \% open canopy $(\mathrm{C})$ in headwater (UP), midstream (MD), and downstream (DN) reaches of survey streams in 6 drainages in the Northern Range of Trinidad. Dotted lines indicate predicted limits of saturation (Newbold 1992).

in riffle than in pool habitats. However, our prediction that epilithic nutrient ratios would decrease as the proportion of active algae increased was not supported. AI (the ratio of chlorophyll $a$ to AFDM) was greater in the dry than in the wet season, but we should have observed lower C:nutrient ratios in the dry season if nutrient ratios reflected increased active algae relative to AFDM. Instead, the higher dryseason C:nutrient ratios that we observed probably reflected increased $C$ fixation by algae rather than a proportional increase in nutrient-poor senescent algae and detritus.

\section{Nutrient availability}

Dissolved nutrient concentrations affected epilithon biomass and stoichiometry in focal and survey streams, but relationships between nutrients and epilithon variables did not always agree with our predictions. For example, focal-stream AFDM decreased with greater $\mathrm{NO}_{3}{ }^{-}$, whereas chlorophyll a content decreased with greater SRP concentrations in both data sets. Newbold (1992) suggested that N may limit productivity in streams at concentrations $\leq 50$ to $60 \mu \mathrm{g} \mathrm{N} / \mathrm{L}$, whereas P limitation might be alleviated at concentrations $>15 \mu \mathrm{g}$ P/L. SRP in the 4 focal streams averaged $\sim 26 \mu \mathrm{g} / \mathrm{L}$ over the course of the study. This range is similar to the range of benthic saturation thresholds reported in previous studies (reviewed by Hill et al. 2009). DIN averaged $\sim 191 \mu \mathrm{g} / \mathrm{L}$, a concentration well above previously suggested thresholds. Thus, nutrient concentrations were relatively high in these streams. Some of the unexpected relationships between nutrients and epilithon biomass observed in our study might be indicative of light limitation or might be linked to seasonal changes in hydrology rather than to temporal patterns in water-column nutrients. SRP concentrations at focal and survey sites were greatest in the dry season, whereas $\mathrm{NO}_{3}{ }^{-}$concentrations were either stable across seasons or greater in the wet than in the dry season (e.g., focal sites in 2008). Our study was not designed to identify the catchment-scale mechanisms behind seasonality in nutrient concentrations, but our data are consistent with dilution of SRP in high-flow conditions (e.g., Triska et al. 2006) and leaching of soil N under wet conditions (Goller et al. 2006, Singh and Kashyap 2007). Links between hydrology and nutrient concentrations may explain why AFDM was negatively associated with $\mathrm{NO}_{3}{ }^{-}$and positively correlated with SRP in our study. Significantly lower chlorophyll $a$ in both the focal and survey sites with increasing SRP might be a result of factors associated with stable hydrology rather than a direct effect of $\mathrm{P}$ availability on epilithon abundance.

In line with our hypotheses, the $\mathrm{P}$ content of epilithon increased with increasing SRP concentrations, and $\mathrm{C}: \mathrm{N}$ ratios decreased with increasing concentrations of $\mathrm{NH}_{4}{ }^{+}$. However, other results were not consistent with stoichiometric theory. For example, $\mathrm{NO}_{3}{ }^{-}$and $\mathrm{NH}_{4}{ }^{+}$were positively correlated with 


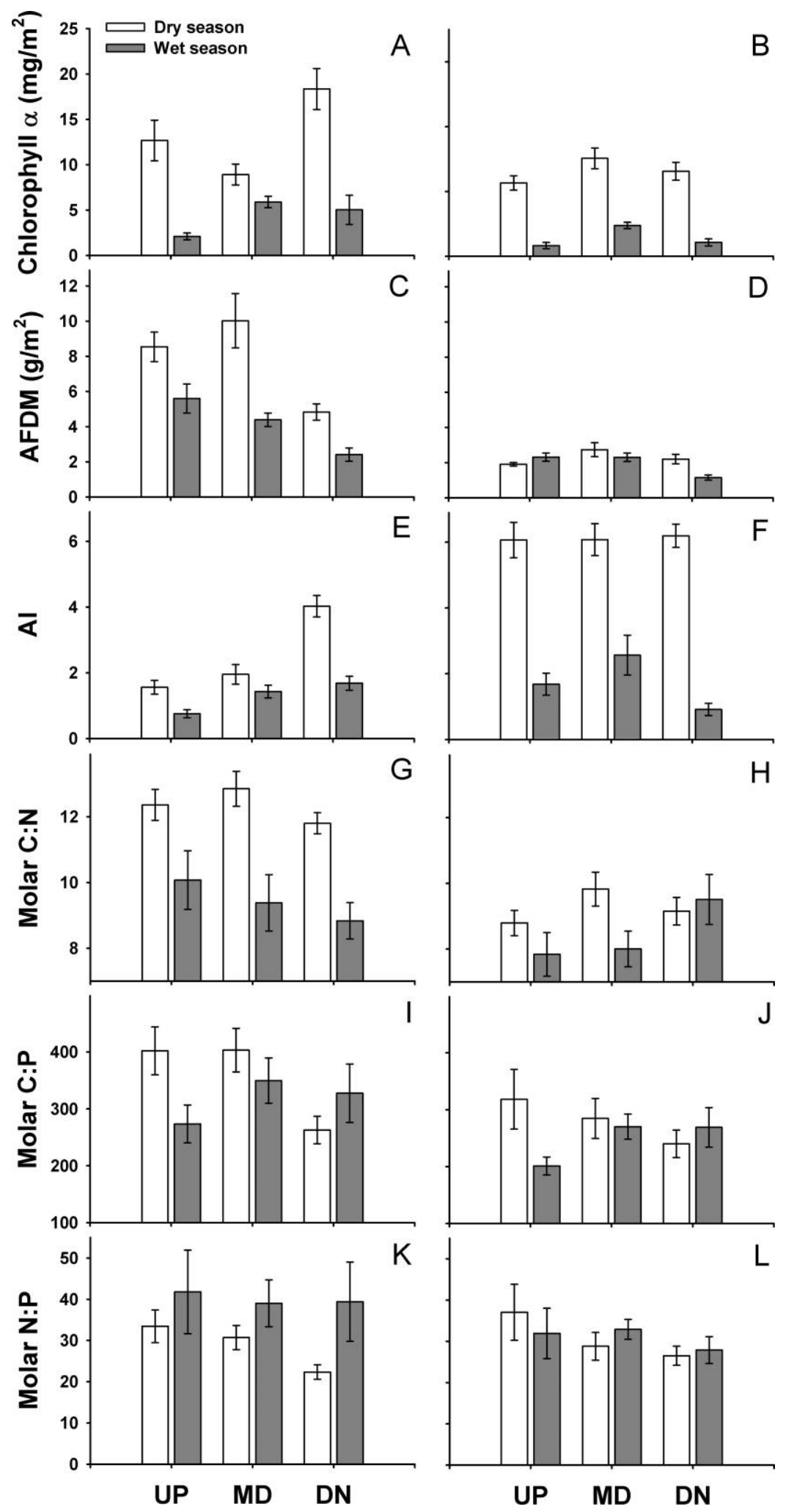

FIG. 7. Mean ( $\pm 1 \mathrm{SE})$ epilithon chlorophyll $a(\mathrm{~A}, \mathrm{~B})$, ash-free dry mass (AFDM) (C, D), autotrophic index (AI) (E, F), molar C:N $(G, H), C: P(I, J)$, and N:P (K, L) in pool (A, C, E, G, I, K) and riffle (B, D, F, H, J, L) habitats at survey streams in wet and dry seasons. 2007 wet-season biomass data (chlorophyll $a$, AFDM, AI) were removed (see text for explanation). 
epilithon P content in the survey streams (decreased $\mathrm{N}: \mathrm{P}$ and C:P ratios) but not in focal streams. The survey streams had a larger gradient of $\mathrm{P}$ availability than did focal streams (where SRP was often $<15 \mu \mathrm{g}$ $\mathrm{P} / \mathrm{L}$ ), so available $\mathrm{NO}_{3}{ }^{-}$and $\mathrm{NH}_{4}{ }^{+}$in the water column may have increased $\mathrm{P}$ assimilation via production of enzymes required for $\mathrm{P}$ acquisition (Arrigo 2005). However, this hypothesis will require further investigation.

\section{Light availability}

Primary production in Trinidadian streams (Grether et al. 2001, TNH, unpublished data) and in other small forested tropical streams is often light limited (Davies et al. 2008). Variation in light among focal streams was quite large, especially when sites were compared with the experimentally thinned reach at TAY, which was 2 to $5 \times$ more open than the other focal streams. For comparison, Hill et al. (1995) found that a temperate Tennessee stream was light-limited until $\sim 7$ moles quanta $\mathrm{m}^{-2} \mathrm{~d}^{-1}$, and this value was exceeded among focal streams only at the cleared reach of TAY. These results are consistent with our observations that chlorophyll $a$ increased in focal and survey streams with light availability and did not appear to be directly linked to nutrient availability.

Available light was positively related to epilithon $\mathrm{C}: \mathrm{P}$ only in survey streams, where the range of $\mathrm{P}$ concentrations was greater than in the focal streams. However, available light was negatively related to epilithon C:N in the focal streams, and epilithon N:P increased with \% open canopy in survey streams. These results are contrary to the predictions of the LNH that C:N should increase with light, C-fixation rates, and reduced cellular chlorophyll $a$ concentrations (Sterner et al. 1997, Sterner and Elser 2002). Ours is not the first study to produce results that conflict with LNH predictions. For example, Liess et al. (2009) found that increased light was associated with decreased C:N, and Hill and Fanta (2008) found no relationship between light and $\mathrm{P}$ content. The stoichiometric changes we observed may be the result of changes in epilithon community composition rather than changes in cellular physiology.

\section{Synthesis and implications}

Primary production is an important energy source in temperate and tropical streams (Minshall 1978, Brito et al. 2006, Lau et al. 2009), but more research is required to make meaningful comparisons across broad latitudinal ranges (Wantzen et al. 2006, Boyero et al. 2009). The seasonal and habitat-specific shifts in $\mathrm{C}: \mathrm{N}: \mathrm{P}$ ratios we observed suggest that flow dictates epilithon abundance and nutrient quality, presumably by removing detrital $C$ or by decreasing $C$ fixation. One implication of our results is that organisms that cannot or do not feed selectively on epilithon may be susceptible to seasonal variation in food quality and may shift from energy to nutrient limitation during periods of stable flow. For organisms capable of selective feeding, habitat choice may mediate seasonal shifts in quality because epilithon had consistently higher chlorophyll $a$ and nutrient content in riffles than in pools, thereby providing habitat-dependent variation in food quality.

Variability in epilithon composition also may affect the elemental composition of consumers. Vertebrate consumers are generally considered to be homeostatic, but Small and Pringle (2010) showed that increased resource quality elevated the nutrient content of secondary producers in Costa Rican streams. They suggested that this shift might have important implications for organisms at higher trophic levels. In support of this hypothesis, Dickman et al. (2008) demonstrated that C:P ratios of carnivorous fish were significantly related to the nutrient quality of phytoplankton, which in turn was mediated by light and nutrients. In Trinidadian streams, local site conditions explain stoichiometric variation in Trinidadian guppies (El-Sabaawi et al. 2012), which use epilithon as a food source (Zandonà et al. 2011), and influence $N$ recycling (Palkovacs et al. 2009, Bassar et al. 2010). The effect of food quality on higher trophic levels in these systems is poorly understood, but our data indicate that spatial and temporal variation in epilithon quality responds to physical and chemical drivers and provide an initial step toward understanding how bottom-up factors influence food quality in tropical streams.

\section{Conclusions}

Our results suggest that explicit and integrated consideration of flow, nutrient, and light variables is necessary to provide a predictive framework for understanding epilithon biomass and nutrient fluxes between inorganic nutrient pools, primary producers, and higher trophic levels. Flow and habitat variables were useful for modeling epilithon biomass and stoichiometry, but our predictions based on the LNH were only partially supported. Nutrient availability consistently increased the nutrient content of epilithon as predicted, but the effects of light were often insignificant or contrary to our hypotheses. This result suggests that the effects of light on epilithon stoichiometry in field conditions are complex and may differ through time and space by interacting with 
other unmeasured variables. More effort is needed to elucidate the effects of these interacting controls on epilithon, especially in natural settings, to refine predictions and improve existing stoichiometric frameworks such as the LNH.

\section{Acknowledgements}

We thank Keeley MacNeill, Sarah Collins, David Owens, Drew Tyre, Andrés Lopez-Sepulcre, Cathleen McFadden, Joseph Travis, Jason Howard, Carl Fitzjames, and 2 anonymous referees for their assistance and helpful comments. We thank the Water and Sewerage Authority of Trinidad and Tobago, the University of the West Indies at St. Augustine, the Ramlal family, and the Asa Wright Nature Centre for permission to access various sites and for use of facilities. This work was supported by a National Science Foundation Frontiers in Integrative Biological Research (FIBR) Grant to DNR and others (NSF-FIBR, DEB-0623632).

\section{Literature Cited}

ARrigo, K. R. 2005. Marine microorganisms and global nutrient cycles. Nature 437:349-355.

Bassar, R. D., M. C. Marshall, A. Lopez-Sepulcre, E. Zandonà, S. K. Auer, J. Travis, C. M. Pringle, A. S. Flecker, S. A. Thomas, D. F. Fraser, AND D. N. ReZnick. 2010. Local adaptation in Trinidadian guppies alters ecosystem properties. Proceedings of the National Academv of Sciences of the United States of America 107:3616-3621.

Biggs, B. J. F., AND M. E. Close. 1989. Periphyton biomass dynamics in gravel bed rivers: the relative effects of flow and nutrients. Freshwater Biologv 22:209-231.

Biggs, B. J. F., D. G. Goring, AND V. I. NiKora. 1998. Subsidy and stress responses of stream periphyton to gradients in water velocity as a function of community growth form. Iournal of Phycology 34:598-607.

Biggs, B. J. F., AND H. A. ThOMSEN. 1995. Disturbance in stream periphyton by perturbations in shear stress: time to structural failure and differences in community resistance. Iournal of Phycology 31:233-241.

Boyero, L., A. Ramírez, D. Dudgeon, and R. G. Pearson. 2009. Are tropical streams really different? Iournal of the North American Benthological Societv 28:397-403.

Brito, E. F., T. P. Moulton, M. L. DE SOuZA, And S. E. Bunn. 2006. Stable isotope analysis indicates microalgae as the predominant food source of fauna in a coastal forest stream, south-east Brazil. Austral Ecology 31: 623-633.

Carpenter, S. R., N. F. Caraco, D. L. Correll, R. W. Howarth, A. N. Sharpley, AND V. H. Smith. 1998. Nonpoint pollution of surface waters with phosphorus and nitrogen. Ecological Applications 8:559-568.

Cross, W. F., J. P. Benstead, P. C. Frost, and S. A. Thomas. 2005. Ecological stoichiometry in freshwater benthic systems: recent progress and perspectives. Freshwater Biology 50:1895-1912.

Davies, P. M., S. E. Bunn, and S. K. Hamilton. 2008. Primary production in tropical streams and rivers. Pages 23-42 in D. Dudgeon (editor). Tropical stream ecology. Elsevier Science, London, UK.

Day, M. J., And M. S. Chenoweth. 2004. The karstlands of Trinidad and Tobago, their land use and conservation. Geographical Journal 170:256-266.

Dickman, E. M., J. M. Newell, M. J. GonzÁlez, and M. J. VANNI. 2008. Light, nutrients and food-chain length constrain planktonic energy transfer efficiency across multiple trophic levels. Proceedings of the National Academv of Sciences of the United States of America 105:18408-18412.

Dickman, E. M., M. J. Vanni, And M. J. Horgan. 2006. Interactive effects of light and nutrients on phytoplankton stoichiometry. Oecologia (Berlin) 149:676-689.

Diggle, P. J., P. Heagerty, K. Y. Liang, and S. L. Zeger. 2002. Analysis of longitudinal data. $2^{\text {nd }}$ edition. Oxford University Press, Oxford, UK.

DodDs, W. K., AND B. J. F. Biggs. 2002. Water velocity attenuation by stream benthic algae in relation to growth form and architecture. Iournal of the North American Benthological Society 21:2-15.

Dodds, W. K., R. E. Hutson, A. C. Eichem, M. A. Evans, D. A. GudDER, K. M. Fritz, AND L. GRAy. 1996. The relationship of floods, drying, flow and light to primary production and producer biomass in a prairie stream. Hydrobiologia 333:151-159.

DodDs, W. K., And M. R. WhiLes. 2010. Freshwater ecology: concepts and environmental applications of limnology. Academic Press, San Diego, California.

El-SabaAwi, R. W., E. Zandonà, T. J. Kohler, M. C. Marshall, J. M. Moslemi, J. Travis, A. López-Sepulcre, R. Ferrier, C. M. Pringle, S. A. Thomas, D. Reznick, and A. S. FLECKER. 2012. Widespread intraspecific organismal stoichiometry among populations of the Trinidadian guppy (Poecilia reticulata). Functional Ecology. doi: 10.1111/ j.1365-2435.2012.01974.x.

Fanta, S. E., W. R. Hill, T. B. Smith, And B. J. Roberts. 2010. Applying the light: nutrient hypothesis to stream periphyton. Freshwater Biology 55:931-940.

Flotemersch, J. E., J. B. Stribling, and M. J. Paul. 2006. Concepts and approaches for the bioassessment of nonwadeable streams and rivers. EPA 600-R-06-127. US Environmental Protection Agency, Cincinnati, Ohio.

Francoeur, S. N., AND B. J. F. BigGs. 2006. Short-term effects of elevated velocity and sediment abrasion on benthic algal communities. Hvdrobiologia 561:59-69.

Francoeur, S. N., B. J. F. BigGS, AND R. L. Lowe. 1998. Microform bed clusters as refugia for periphyton in a flood-prone headwater stream. New Zealand Journal of Marine and Freshwater Research 32:363-374.

Frost, P. C., H. Hillebrand, AND M. Kahlert. 2005. Low algal content and its effects on the C:P stoichiometry of periphyton. Freshwater Biology 50:1800-1807.

Geider, R. J., H. L. MacIntyre, and T. M. Kana. 1998. A dynamic regulatory model of phytoplanktonic acclimation 
to light, nutrients, and temperature. Limnology and Oceanography 43:679-694.

Goller, R., W. Wilcke, K. Fleischbein, C. Valarezo, and W. ZECH. 2006. Dissolved nitrogen, phosphorus, and sulfur forms in the ecosystem fluxes of a montane forest in Ecuador. Biogeochemistry 77:57-89.

Gore, J. A. 2006. Discharge measurements and streamflow analysis. Pages 51-78 in F. R. Hauer, and G. A. Lamberti (editors). Methods in stream ecology. $2^{\text {nd }}$ edition. Academic Press, San Diego, California.

Grether, G. F., D. F. Millie, M. J. Bryant, D. N. Reznick, and W. Mayea. 2001. Rainforest canopy cover, resource availability, and life history evolution in guppies. Ecology 82:1546-1559.

Guariento, R. D., L. S. Carneiro, A. Caliman, R. L. Bozelli, AND F. A. Esteves. 2011. How light and nutrients affect the relationship between autotrophic and heterotrophic biomass in a tropical blackwater periphyton community. Aquatic Ecology 45:561-569.

Hedges, J. I., AND J. H. Stern. 1984. Carbon and nitrogen determinations of carbonate-containing solids. Limnologv and Oceanography 29:657-663.

Helson, J. E., D. D. Williams, and D. Turner. 2006. Larval chironomid community organization in four tropical rivers: human impacts and longitudinal zonation. Hydrobiologia 559:413-431.

Hill, W. R., and S. E. Fanta. 2008. Phosphorus and light colimit periphyton growth at subsaturating irradiances. Freshwater Biology 53:215-225.

Hill, W. R., S. E. FANTA, AND B. J. RoberTs. 2009. Quantifying phosphorus and light effects in stream algae. Limnologv and Oceanography 54:368-380.

Hill, W. R., B. J. Roberts, S. N. Francoeur, and S. E. Fanta. 2011. Resource synergy in stream periphyton communities. Ecology 99:454-463.

Hill, W. R., M. G. RYon, And E. M. Schilling. 1995. Light limitation in a stream ecosystem: responses by primary producers and consumers. Ecology 76:1297-1309.

Hillebrand, H., AND M. KAHLERT. 2001. Effect of grazing and nutrient supply on periphyton biomass and nutrient stoichiometry in habitats of different productivity. Limnology and Oceanography 46:1881-1898.

Hillebrand, H., G. DE MontPellier, AND A. Liess. 2004. Effects of macrograzers and light on periphyton stoichiometry. Oikos 106:93-104.

Holmes, R. M., A. Aminot, R. Kerouel, B. A. Hooker, and B. J. Peterson. 1999. A simple and precise method for measuring ammonium in marine and freshwater ecosystems. Canadian Journal of Fisheries and Aquatic Sciences 56:1801-1808.

Jeyasingh, P. D., And L. J. Weider. 2007. Fundamental links between genes and elements: evolutionary implications of ecological stoichiometry. Molecular Ecology 16: 4649-4661.

Kemp, M. J., And W. K. DodDs. 2001. Spatial and temporal patterns of nitrogen concentrations of pristine and agriculturally-influenced prairie streams. Biogeochemistry 53:125-141.
Kohler, T. J., J. N. Murdock, K. B. Gido, and W. K. Dodds. 2011. Nutrient loading and grazing by the minnow Phoxinus erythrogaster shift periphyton abundance and stoichiometry in mesocosms. Freshwater Biology 56: 1133-1146.

Lau, D. C. P., K. M. Y. Leung, and D. Dudgeon. 2009. Are autochthonous foods more important than allochthonous resources to benthic consumers in tropical headwater streams? Iournal of the North American Benthological Societv 28:426-439.

LEMMON, P. E. 1956. A spherical densitometer for estimating forest overstory density. Forest Science 2:314-320.

Liess, A., K. Lange, F. Schulz, J. J. Piggott, C. D. Matthaei, AND C. R. TownSEND. 2009. Light, nutrients and grazing interact to determine diatom species richness via changes to productivity, nutrient state, and grazer activity. Iournal of Ecology 97:326-336.

Loeb, S. L. 1981. An in situ method for measuring the primary productivity and standing crop of the epilithic periphyton community in lentic systems. Limnology and Oceanography 26:394-399.

Minshall, G. W. 1978. Autotrophy in stream ecosystems. BioScience 28:767-770.

MurPhy, J., AND J. P. RiLeY. 1962. A modified single solution method for determination of phosphate in natural waters. Analvtica Chimica Acta 26:31-36.

NAKAZAWA, T. 2011. The ontogenetic stoichiometric bottleneck stabilizes herbivore-autotroph dynamics. Ecological Research 26:209-216.

Neill, C., L. A. Deegan, S. M. Thomas, and C. C. Cerri. 2001. Deforestation for pasture alters nitrogen and phosphorus in small Amazonian streams. Ecological Applications 11:1817-1828.

Newbold, J. D. 1992. Cycles and spirals of nutrients. Pages 379-408 in P. Calow and G. E. Petts (editors). The rivers handbook: hydrological and ecological principles. Volume 1. Blackwell Scientific Publishing, Oxford, UK.

Palkovacs, E. P., M. C. Marshall, B. A. Lamphere, B. R. Lynch, D. J. Weese, D. F. Fraser, D. N. Reznick, C. M. Pringle, AND M. T. KinNison. 2009. Experimental evaluation of evolution and coevolution as agents of ecosystem change in Trinidadian streams. Philosophical Transactions of the Roval Society B: Biological Sciences 364:1617-1628.

Parsons, T. R., Y. Maita, And C. M. Lalli. 1984. A manual of chemical and biological methods for seawater analysis. Pergamon Press, Oxford, UK.

PinHeIro, J., AND D. BAtES. 2001. Mixed effects models in S and S-plus. Springer, Berlin, Germany.

Pinheiro, J., D. Bates, S. DebRoy, and D. Sarkar. 2006. nlme: an $\mathrm{R}$ package for fitting and comparing Gaussian linear and nonlinear mixed-effects models. $\mathrm{R}$ project for statistical computing, Vienna, Austria. (Available from: http:/ /www.stats.bris.ac.uk/R/)

Quinn, G. P., And M. J. Keough. 2002. Experimental design and data analysis for biologists. Cambridge University Press, Cambridge, UK. 
Sanches, L. F., R. D. Guariento, A. Caliman, R. L. Bozelli, AND F. A. Esteves. 2011. Effects of nutrients and light on periphytic biomass and nutrient stoichiometry in a tropical black-water aquatic ecosystem. Hydrobiologia 669:35-44.

Schade, J. D., J. F. Espeleta, C. A. Klausmeier, M. E. McGroddy, S. A. Thomas, And L. Zhang. 2005. A conceptual framework for ecosystem stoichiometry: balancing resource supply and demand. Oikos 109:40-51.

SingH, J. S., AND A. K. KashyAP. 2007. Variations in soil Nmineralization and nitrification in seasonally dry tropical forest and savanna ecosystems in Vindhyan region, India. Tropical Ecology 48:27-35.

Small, G. E., And C. M. Pringle. 2010. Deviation from strict homeostasis across multiple trophic levels in an invertebrate consumer assemblage exposed to high chronic phosphorus enrichment in a Neotropical stream. Oecologia (Berlin) 162:581-590.

SteRnER, R. W., AND J. J. ELSER. 2002. Ecological stoichiometry: the biology of elements from molecules to the biosphere. Princeton University Press, Princeton, New Jersey.

Sterner, R. W., J. J. Elser, E. J. Fee, S. J. GuildFord, and T. H. ChrzanOwsKi. 1997. The light: nutrient ratio in lakes: the balance of energy and materials affects ecosystem structure and process. American Naturalist 150:663-684.

TaYlor, B. W., C. F. KeEP, R. O. Hall, B. J. Koch, L. M. Tronstad, A. S. Flecker, and A. J. Ulseth. 2007. Improving the fluorometric ammonium method: matrix effects, background fluorescence, and standard additions. Iournal of the North American Benthological Society 26:167-177.

Thimijan, R. W., AND R. D. HeIns. 1983. Photometric, radiometric, and quantum light units of measure: a review of procedures for interconversion. HortScience 18:818-822.

Triska, F. J., C. M. Pringle, J. H. Duff, R. J. Avanzino, A. Ramirez, M. Ardon, AND A. P. Jackman. 2006. Soluble reactive phosphorus transport and retention in tropical, rainforest streams draining a volcanic and thermally active landscape in Costa Rica: long-term concentration patterns, pore water environment and response to ENSO events. Biogeochemistry 81:131-143.

Wantzen, K. M., A. Ramírez, And K. O. Winemiller. 2006. New vistas in Neotropical stream ecology: preface. Iournal of the North American Benthological Society 25: 61-65.

West, B. T., K. B. Welch, and A. T. Galecki. 2006. Linear mixed models: a practical guide using statistical software. Chapman and Hall/CRC Press, London, UK.

WetzeL, R. G. 2001. Limnologv: lake and river ecosvstems. $3^{\text {rd }}$ edition. Academic Press, San Diego, California.

Zandonà, E., S. K. Auer, S. S. Kilham, J. L. Howard, A. LópezSepulcre, M. P. O'Connor, R. D. Bassar, A. Osorio, C. M. Pringle, And D. N. Reznick. 2011. Diet quality and prey selectivity correlate with life histories and predation regime in Trinidadian guppies. Functional Ecology 25: 964-973.

ZuUr, A. F., E. N. IENO, AND C. S. Elphick. 2010. A protocol for data exploration to avoid common statistical problems. Methods in Ecology and Evolution 1:3-14.

Zuur, A. F., E. N. Ieno, N. J. Walker, A. A. Saveliev, and G. M. Sмітн. 2009. Mixed effects models and extensions in ecology with R. Springer, New York.

Received: 14 October 2011 Accepted: 20 June 2012 